\title{
Potential Abscission Agents for Raisin, Table, and Wine Grapes
}

\author{
Matthew W. Fidelibus ${ }^{1}$ and Kimberley A. Cathline \\ Department of Viticulture and Enology, University of California, One Shields \\ Avenue, Davis, CA 95616-8749
}

\section{Jacqueline K. Burns}

Horticultural Sciences Department, Citrus Research and Education Center, University of Florida, Institute of Food and Agricultural Sciences, 700 Experiment Station Road, Lake Alfred, FL 33850-2299

Additional index words. 'Cabernet Sauvignon', coronatine, 'Crimson Seedless', mechanical harvest, 'Merlot', methyl jasmonate, 'Thompson Seedless', Vitis vinifera L.

\begin{abstract}
Effective abscission agents that decrease fruit detachment force (FDF) are sought by the California raisin industry to improve the continuous tray mechanical harvesting method. Such agents might also enable mechanical harvest of table and wine grapes (Vitis vinifera L.), but few agents are known to be effective for grape. Thus, methyl jasmonate (MeJA) and six other compounds known to stimulate abscission of other fruits were screened for their ability to reduce FDF of mature 'Thompson Seedless' grapes. Most compounds tested reduced FDF to some extent, but MeJA was particularly effective. Solutions containing between 45 and 4500 ppm MeJA reduced FDF by at least $50 \%$ to $85 \%$ compared with nontreated fruits. Application of 2250 and $4500 \mathrm{ppm}$ MeJA to 'Thompson Seedless' vines caused $25 \%$ to $50 \%$ fruit drop, respectively, within $10 \mathrm{~d}$ after treatment (DAT). The efficacy of MeJA was verified in a second experiment in which solutions of $0,1125,2250$, or $4500 \mathrm{ppm}$ MeJA were applied to clusters of 'Crimson Seedless' grapes; at $14 \mathrm{DAT}$, FDF declined as a linear function of MeJA applied. The grapes did not abscise, but berries treated with 2250 to $4500 \mathrm{ppm}$ MeJA had slightly lower soluble solids than nontreated fruits. Solutions of 0 or $4500 \mathbf{~ p p m ~ M e J A ~ a p p l i e d ~ t o ~}$ clusters of 'Cabernet Sauvignon' and 'Merlot' grapevines reduced FDF by $66 \%$ and $75 \%$, respectively. Fruit drop was estimated to be less than $10 \%$. Thus, a solution containing up to $4500 \mathrm{ppm}$ MeJA may be an effective abscission agent to facilitate mechanical harvest of 'Cabernet Sauvignon' or 'Merlot'.
\end{abstract}

Most California raisin growers rely on hand labor to pick their grapes and place them on paper trays between the vine rows to dry. However, labor has become increasingly scarce and expensive in recent years, so many raisin growers have begun to use mechanical harvesters to shake the berries from the vines into hoppers from which they are spread onto a length of paper known as a "continuous tray" (Christensen, 2000a). The continuous tray method requires fewer laborers than the traditional hand-harvesting method and can reduce production cost (Vasquez et al., 2007). However, the harvest machines, which were designed for juice and wine grapes, can cause sufficient mechanical damage to grapes to render them unsuitable for raisin-making.

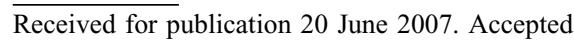
for publication 8 Aug. 2007.

This work was made possible by a grant from the California Raisin Marketing Board.

We are grateful to Mickael Olivon and Jorge Osorio Aguilar for technical assistance and to L. Peter Christensen and M. Cecilia Peppi for their helpful comments on an earlier draft of this manuscript.

${ }^{1}$ To whom reprint requests should be requested; e-mail mwf@uckac.edu
Weaver and Pool (1968) showed that morphactins weakened the attachment of mature grapes to their clusters, but these synthetic compounds would likely be prohibitively expensive to register, particularly because they are not used on other fruit crops. Ethephon sometimes promotes the loosening of grapes, but its efficacy is very inconsistent (Christensen, 2000b). No other compounds were known to promote loosening or abscission of mature grape berries.

To identify new potential abscission agents for grape, candidate compounds were obtained that met one or more of the following criteria: registered for use on other fruit crops, have the potential to be cost-effective, or may be registered as a biopesticide. Several abscission agents that met one or more of those criteria were identified for citrus (Burns et al., 2003; Hartmond et al., 2000; Yuan and Burns, 2004). Thus, the objective of this research was to evaluate the efficacy of such compounds on grapes.

\section{Materials and Methods}

'Thompson Seedless' experiment. The first experiment was conducted in a 40 year-old 'Thompson Seedless' vineyard at the Kearney Agricultural Center, Parlier, CA. The site was typical of conventional raisin vineyards with head-trained, cane-pruned vines on a two-wire T-shaped trellis with a 0.6- $\mathrm{m}$ cross arm. The soil was a deep Hanford fine sandy loam.

The vineyard was divided into plots consisting of vine sections (within-row spaces between two adjacent vine trunks) of uniform appearance and crop load. Each plot was surrounded by guard vines within and between rows. Treatments consisted of 21 different solutions made up of various potential abscission agents (Table 1), one control consisting of water with adjuvant added, and another control consisting of harvest pruning (HP) for a total of 23 different treatments. The materials were applied at concentrations spanning a range known to be effective for citrus. Because the concentrations varied widely between materials, each solution was considered a different treatment, and a randomized complete block design was used. All treatments, except for coronatine, were replicated four times. As a result of a lack of material, coronatine was only applied to two plots; therefore, data from that treatment were not subjected to statistical analysis although observations were made.

Beginning in mid-Aug. 2006, composite berry samples were collected weekly to monitor soluble solids accumulation by the fruits. Samples consisted of $\approx 100$ berries collected from the top, middle, and bottom of $\approx 33$ randomly selected clusters. Berries were homogenized in a blender, their juice filtered, and soluble solids measured with a temperature-compensating digital refractometer (Palette 101; Atago, Farmingdale, NY). Fruits amassed sufficient soluble solids for raisin-making (greater than $19^{\circ}$ Brix) by 2 Sept. 2006. On that date, potential abscission 
Table 1. Potential abscission agents tested on grape.

\begin{tabular}{|c|c|c|}
\hline Compound & Description & Concentrations tested \\
\hline $\mathrm{ACC}$ & $\begin{array}{l}\text { The ethylene biosynthetic precursor; can readily be converted to } \\
\text { ethylene in plants (Wang et al., 2002), but uptake can be an issue; } \\
\text { like ethephon, may induce nonspecific abscission }\end{array}$ & 50 and $150 \mathrm{ppm}$ \\
\hline $\begin{array}{l}\text { 5-chloro-3-methyl-4-nitro-1H-pyrazole } \\
\text { (CMNP) }\end{array}$ & $\begin{array}{l}\text { Specific for mature citrus fruit loosening within a wide concentration } \\
\text { range (Burns, 2002) }\end{array}$ & $20,200,1000$, and $2000 \mathrm{ppm}$ \\
\hline Coronatine & $\begin{array}{l}\text { A natural compound produced by fermentation with Pseudomonas } \\
\text { syringae pv glycinea; is classified as a methyl jasmonate biological } \\
\text { mimic; loosens mature citrus fruit (Burns et al., 2003); causes transient } \\
\text { chlorosis; expect } \approx 10 \% \text { defoliation; does not cause young fruit } \\
\text { abscission }\end{array}$ & $200 \mathrm{ppm}$ \\
\hline Dikegulac & $\begin{array}{l}\text { A pinching agent; in citrus, is thought to disrupt auxin-ethylene balance } \\
\text { and accelerate abscission (Pozo et al., 2004); expect 15\% to } 20 \% \text { leaf loss } \\
\text { at certain times of the season }\end{array}$ & $20,200,1000$, and $2000 \mathrm{ppm}$ \\
\hline Maxcel & Benzyladenine, used as an apple-thinning agent (Dennis and Hull, 2003) & 20,200 , and $600 \mathrm{ppm}$ \\
\hline Methyl jasmonate & $\begin{array}{l}\text { A natural compound found in plants; thought of as an "octadecanoid } \\
\text { signal" derived from lipid signaling; can advance many } \\
\text { senescence-related processes such as color change; loosens } \\
\text { mature citrus fruit but causes } \approx 20 \% \text { defoliation when applied to } \\
\text { citrus (Hartmond et al., } 2000 \text { ) }\end{array}$ & $\begin{array}{l}0.2,2,10, \text { and } 20 \mathrm{~mm} \\
\quad \approx 45,445,2240, \text { and } \\
4485 \mathrm{ppm}\end{array}$ \\
\hline VBC-30050 & Proprietary compound & 20,200 , and $500 \mathrm{ppm}$ \\
\hline
\end{tabular}

materials were dissolved or dispersed in water with adjuvant (Latron B-1956; Britz, Parlier, CA). Most solutions were prepared with $0.1 \%(\mathrm{v} / \mathrm{v})$ adjuvant, except for those with methyl jasmonate (MeJA), which required $0.2 \%$ adjuvant to dissolve the material, and control solutions, which consisted of water and adjuvant $(0.2 \% \mathrm{v} / \mathrm{v})$. Immediately after their preparation, solutions were applied to the vines of each plot with a gasolinepowered backpack sprayer (Solo, Newport News, RI) until runoff. Vines within HP plots were not treated with any solutions, but their canes were severed on the same day that solutions were applied.

The soil surface within each plot was covered with ground cloth to collect any berries that might fall from the canopy. Ten days after treatment (DAT), berry abscission was only observed in plots treated with MeJA or coronatine. In those plots and in the control and HP plots, all abscised berries were collected from the ground cloth into paper bags and placed in a forced-air oven $\left(60^{\circ} \mathrm{C}\right)$ until they reached a constant weight. Clusters of grapes on vines from all the plots were carefully harvested and brought into a laboratory where fruit detachment force (FDF) measurements were made. Any grapes that detached from the vines at harvest were considered to be retained by the vine until harvest. These berries were collected into paper bags and placed in a forced-air oven to dry.

Three representative clusters were selected from all the clusters of each plot and 10 rachis sections from the top, middle, and bottom of the three clusters were prepared by cutting the rachis with shears. A berry from each section was then cradled in a jig attached to a force gauge (DPS-11; Imada, Northbrook, IL), and the rachis section was slowly pulled away from the berry until it detached. The force required to detach each berry from the rachis in kilogram-force was recorded as the FDF, and plot means were used for statistical comparisons. The condition of each detached berry was noted, and the berries were placed in paper bags along with all the other berries that were picked from that plot. These berries were also placed in the forced air oven and dried to a constant weight. The proportion of berries that abscised from the vine was calculated on a dry weight basis by dividing the dry weight of the abscised berries in each plot by the combined weight of the retained and abscised berries in that plot. Finally, canopy damage in each plot was inspected visually and assigned a rating of 0 (no obvious foliar damage), 1 (appearance of slight foliar damage), 2 (appearance of moderate foliar damage), or 3 (appearance of severe foliar damage).

Each plot was inspected again on 27 Mar. 2007 when budbreak and shoot growth were evaluated. To evaluate budbreak, plots received one of the following scores: $0=$ shoots emerged from $0 \%$ to $20 \%$ of nodes, $1=$ shoots emerged from $21 \%$ to $40 \%$ of nodes, 2 = shoots emerged from $41 \%$ to $60 \%$ of nodes, 3 = shoots emerged from $61 \%$ to $80 \%$ of nodes, or $4=$ shoots emerged from $81 \%$ to $100 \%$ of nodes. Shoot growth in each plot was also evaluated on a 5-point scale based on the proportion of shoots that had progressed to the five-leaf stage (EichornLorenz stage 12; Eichorn and Lorenz, 1977). A score of 0 indicated that $0 \%$ to $20 \%$ of the shoots had progressed to the five-leaf stage, $1=21 \%$ to $40 \%$ of the shoots progressed to that stage, $2=41 \%$ to $60 \%$ of the shoots, $3=$ $61 \%$ to $80 \%$ of the shoots, and $4=81 \%$ to $100 \%$ of the shoots had progressed to the five-leaf stage.

All quantitative data were subjected to analysis of variance using the general linear models procedure (PROC GLM) of SAS statistical software (SAS Inst., Cary, NC). Duncan's new multiple range test was used to separate treatment means. Interval data, including assessments of canopy damage and measures of return shoot growth, were subjected to Fisher's exact test using the frequency procedure (PROC FREQ) of SAS, and mean comparisons, when appropriate, were made with paired $t$ tests.
'Crimson Seedless' experiment. A second experiment was conducted in a 14-year-old vineyard of own-rooted 'Crimson Seedless' table grapes on open-gable trellises. Individual clusters of grapes were sprayed to runoff with one of four solutions containing 0,1125 , 2250 , or $4500 \mathrm{ppm}$ MeJA and an adjuvant $(0.2 \% \mathrm{v} / \mathrm{v}$; Latron-B 1956). On 20 Sept. 2006, treatments were applied in a randomized, complete block design with clusters as observational units and vines as blocks. Each spray treatment was applied to five replicate clusters. During treatment, clusters were surrounded with plastic shields to protect other clusters from overspray and runoff. The day after treatment, each cluster was enclosed in a plastic mesh bag to collect any berries that might abscise. Clusters were harvested on 2 Oct. 2006. Ten rachis sections were collected from each cluster and FDF was measured as described previously. The condition of the detached berries was noted, and the berries from each cluster were weighed and homogenized in a blender. Juices were filtered and soluble solids, $\mathrm{pH}$, and titratable acidity of the filtered juices were determined using standard methods.

All data were subjected to analysis of variance using the general linear models procedure (PROC GLM) of SAS statistical software (SAS Inst.). Duncan's new multiple range test was used to separate treatment means. To determine the relationship between FDF and the concentration of MeJA applied, treatment means were subjected to regression analysis (Gomez and Gomez, 1984) using SigmaPlot software (Systat Software, Point Richmond, CA).

'Cabernet Sauvignon' and 'Merlot' experiment. A third experiment was conducted in a 9-year-old vineyard of ownrooted 'Cabernet Sauvignon' and 'Merlot' grapevines on a vertical two-wire trellis. Whole vines were sprayed to runoff on 20 Sept. 2006 with solutions containing 0 or $4500 \mathrm{ppm}$ MeJA and an adjuvant (Latron B$1956 ; 0.2 \% \mathrm{v} / \mathrm{v}$ ) in a completely randomized design replicated four times. On 6 Oct. 2006, 
four representative clusters were collected from each of four vines and 10 rachis sections were prepared from each cluster. Fruit detachment force was measured from berries attached to each section as described previously. Condition of the detached berries was noted, and all the berries from each cluster were counted, weighed, and homogenized in a blender. The juice from each sample was filtered and soluble solids, $\mathrm{pH}$, and titratable acidity of the filtered juices were determined using standard methods. All data were subjected to analysis of variance using the general linear models procedure (PROC GLM) of SAS statistical software (SAS Inst.). Duncan's new multiple range test was used to separate treatment means.

\section{Results and Discussion}

'Thompson Seedless' experiment. Within 2 DAT, abscised berries were observed in plots treated with $450 \mathrm{ppm}$ or greater MeJA (data not shown). Berries abscised at the pedicel/fruit interface, leaving a dry, corky, concave scar on the surface of the abscission zone located at the stem end of each berry (Fig. 1). Detached berries were free of stemend tears and other surface damages (Fig. 2). At harvest, 10 DAT, fruit drop was only observed in sprayed plots treated with MeJA or coronatine, so fruit drop was only evaluated in those plots and in the control and HP plots. Fruit drop was insignificant in plots

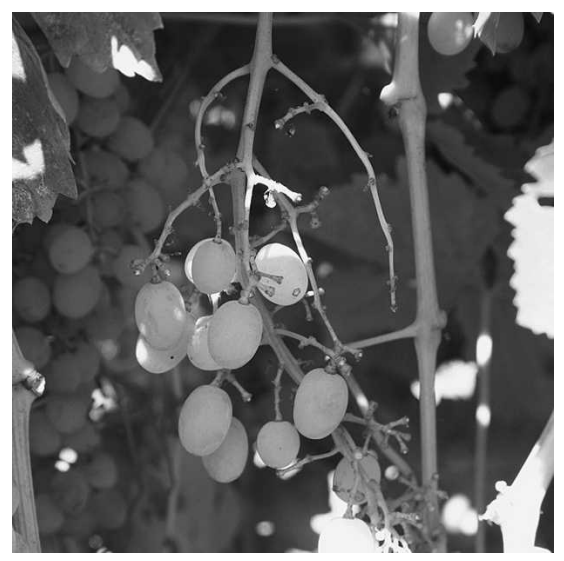

Fig. 1. A cluster of 'Thompson Seedless' grapes from a vine treated $10 \mathrm{~d}$ earlier with a solution of 4500 ppm methyl jasmonate.

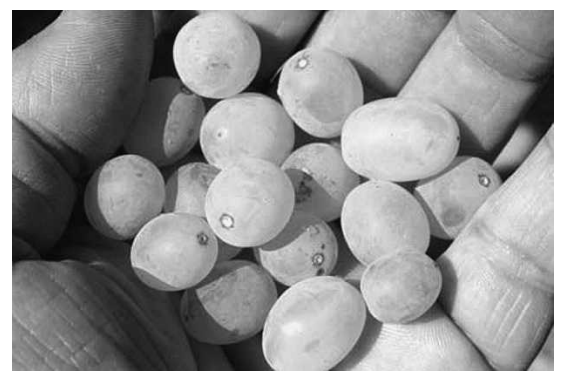

Fig. 2. Berries released from methyl jasmonatetreated clusters were generally free of plugging and tearing. treated with $450 \mathrm{ppm}$ or less MeJA, but within $10 \mathrm{DAT}, 25 \%$ of the berries abscised from vines in plots treated with $2250 \mathrm{ppm}$ MeJA and $50 \%$ of the berries abscised from vines treated with 4500 ppm MeJA (Table 2).

These results are comparable to citrus, when trees treated with solutions of 2250 to 4500 ppm MeJA had FDF values $75 \%$ to $80 \%$ less than fruit from nontreated trees and $\approx 20 \%$ of the fruit on treated trees dropped within 10 DAT (Hartmond et al., 2000). Fruit drop in plots treated with $200 \mathrm{ppm}$ coronatine, a biological mimic of MeJA shown to have abscission activity (Burns et al., 2003), appeared similar to that of vines treated with 2250 ppm MeJA.

Approximately two-thirds of the different solutions tested reduced FDF to some degree (Table 3), but MeJA treatments were the only ones that reduced FDF to values similar to, or lower than, those achieved by HP, the current

Table 2. Percent fruit drop (dry wt/dry wt) from Thompson Seedless grapevines in plots subjected to harvest pruning or to application of solutions containing 0 (control), 45, 450, 2250 , or 4500 ppm methyl jasmonate (MeJA). ${ }^{2}$

\begin{tabular}{lr}
\hline Treatment & $\begin{array}{c}\text { Percent } \\
\text { fruit drop }\end{array}$ \\
\hline Harvest Prune & $0.21 \mathrm{c}^{\mathrm{y}}$ \\
Control & $0.16 \mathrm{c}$ \\
MeJA (45 ppm) & $0.26 \mathrm{c}$ \\
MeJA (450 ppm) & $6.37 \mathrm{c}$ \\
MeJA (2250 ppm) & $26.85 \mathrm{~b}$ \\
MeJA (4500 ppm) & $50.71 \mathrm{a}$
\end{tabular}

${ }^{\mathrm{z}}$ Data were collected $10 \mathrm{~d}$ after treatment.

${ }^{\mathrm{z}}$ Values are plot means, $n=4$. Means followed by a different letter are significantly different according to Duncan's new multiple range test.

Table 3. The effect of different potential abscission agents on fruit detachment force of Thompson Seedless grapevines $10 \mathrm{~d}$ after treatment.

\begin{tabular}{ll}
\hline Treatment & FDF $(\mathrm{kg})$ \\
\hline VBC-30050 (20 ppm) & $0.318 \mathrm{a}^{\mathrm{z}}$ \\
Control & $0.317 \mathrm{ab}$ \\
Dikegulac $(20 \mathrm{ppm})$ & $0.291 \mathrm{abc}$ \\
Dikegulac $(1000 \mathrm{ppm})$ & $0.288 \mathrm{ab}$ \\
Dikegulac $(200 \mathrm{ppm})$ & $0.27 \mathrm{ab}$ \\
ACC $(150 \mathrm{ppm})$ & $0.266 \mathrm{abcd}$ \\
VBC-30050 (20 ppm) & $0.263 \mathrm{bcd}$ \\
ACC (50 ppm) & $0.261 \mathrm{~cd}$ \\
Maxcel (20 ppm) & $0.261 \mathrm{~cd}$ \\
Maxcel (600 ppm) & $0.257 \mathrm{~cd}$ \\
CMNP (20 ppm) & $0.244 \mathrm{~cd}$ \\
VBC-30050 (200 ppm) & $0.243 \mathrm{~cd}$ \\
VBC-30050 (500 ppm) & $0.239 \mathrm{~cd}$ \\
Maxcel (200 ppm) & $0.226 \mathrm{de}$ \\
CMNP (2000 ppm) & $0.182 \mathrm{ef}$ \\
Dikegulac (2000 ppm) & $0.176 \mathrm{efg}$ \\
Methyl jasmonate (45 ppm) & $0.169 \mathrm{fg}$ \\
CMNP (1000 ppm) & $0.161 \mathrm{fg}$ \\
CMNP (200 ppm) & $0.156 \mathrm{fg}$ \\
Methyl jasmonate (450 ppm) & $0.124 \mathrm{gh}$ \\
Harvest Prune & $0.101 \mathrm{hi}$ \\
Methyl jasmonate (2250 ppm) & $0.079 \mathrm{hi}$ \\
Methyl jasmonate (4500 ppm) & $0.052 \mathrm{i}$ \\
\hline Values are treatment means & 4
\end{tabular}

${ }^{\mathrm{z}}$ Values are treatment means, $\mathrm{n}=4$ ten-berry samples. Means followed by a different letter are significantly different according to Duncan's new multiple range test.

$\mathrm{FDF}=$ fruit detachment force. industry standard method for loosening grapes. In fact, the lowest concentration of MeJA tested reduced FDF by half compared with that of nontreated vines, FDF continued to decrease as the concentration of MeJA increased, and the two most concentrated MeJA treatments caused fruit drop. Moreover, MeJA-treated fruit were free of pedicels, whereas numerous fruit harvested from cane-severed plots contained cap-stems. For these reasons, MeJA, and possibly coronatine, appear to have the best potential as an abscission agent for grapes.

Most compounds tested also caused less canopy damage than harvest pruning, a process that destroys $\approx 50 \%$ of the canopy leaf area (Scholefield et al., 1977). In fact, the appearance of vines treated with 450 ppm or less MeJA was similar to that of control vines (data not shown). However, Repka et al. (2001) reported that sustained exposure to $50 \mu \mathrm{M}$ MeJA induced a hypersensitive response in the leaves of 'Limberger' grapevines (Vitis vinifera), and solutions containing greater than 2250 ppm MeJA caused unacceptable levels of defoliation in citrus (Hartmond et al., 2000). Thus, high concentrations of MeJA treatments may have the potential to cause more serious leaf damage to grapes than we observed to date. Nevertheless, treatment with 450 ppm MeJA reduced FDF as effectively as HP without causing unwanted berry abscission or canopy damage. In addition, budbreak and shoot growth the next spring were unaffected by any of the treatments (data not shown). However, shoots from vines treated with 2000 ppm dikegulac had cupped leaves and short internodes when evaluated on 27 Mar. 2007.

'Crimson Seedless' experiment. 'Crimson Seedless' grapes did not abscise from any clusters within 14 DAT, but the highest concentration of MeJA loosened some berries sufficiently that the handling involved in harvesting the clusters caused them to detach. For berries retained after harvest, FDF decreased as a linear function of the concentration of MeJA applied (Fig. 3). These results suggest that $\mathrm{MeJA}$ acts directly on the target organs, and foliar sprays were not necessary to promote loosening of grapes, an observation that has also been made for citrus (Hartmond et al., 2000). Berries detached from clusters treated with high concentrations of MeJA generally sustained less mechanical damage from hand harvest such as tearing the skin around the pedicel/fruit attachment point than berries from clusters that were not treated with MeJA. This effect could facilitate preparation of sound individual grape berries for use in the food service industry or for retail sale.

As observed in 'Thompson Seedless', 'Crimson Seedless' berries detached from clusters treated with MeJA formed an abscission layer so the stem ends of the berries usually had a dry, corky, concave scar. Treatment with MeJA did not affect berry fresh weight, but application of $2250 \mathrm{ppm}$ or greater MeJA slightly reduced juice soluble solids (Table 4). Why this treatment might 


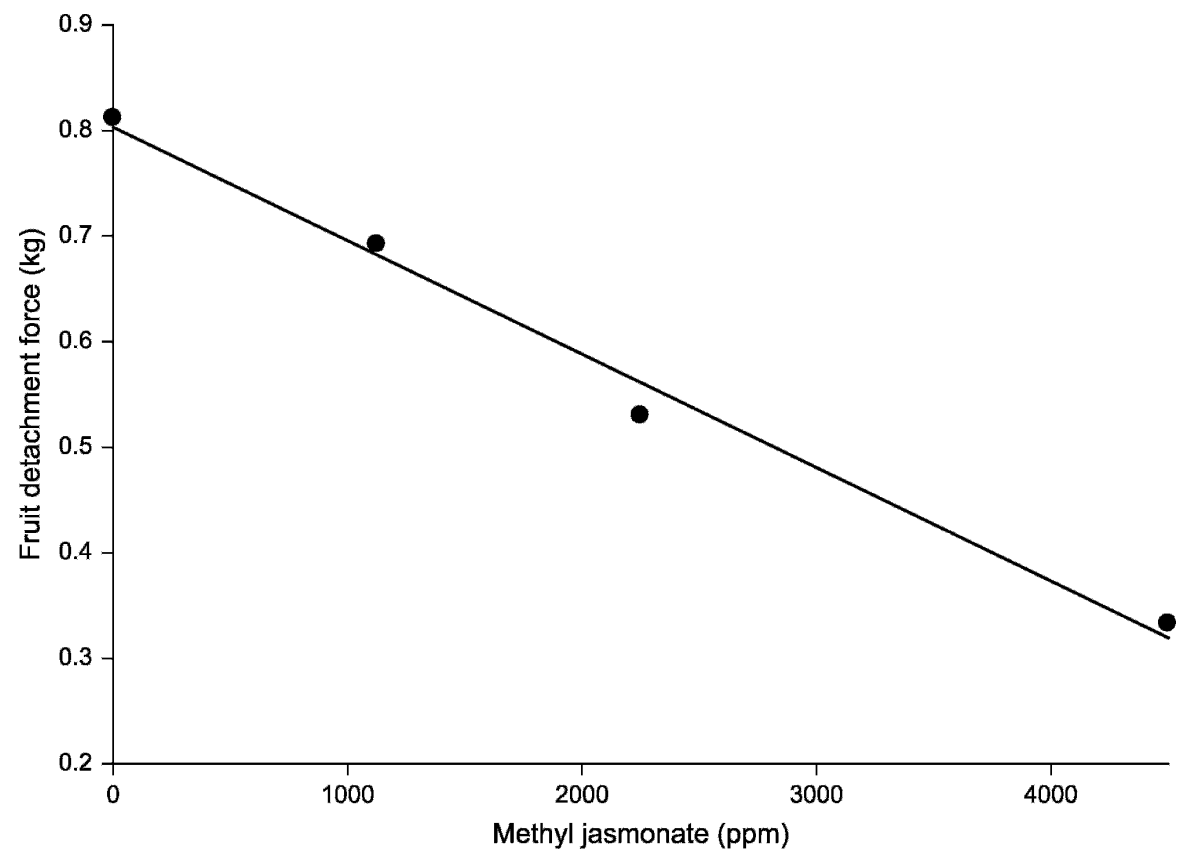

Fig. 3. Average fruit detachment force of 'Crimson Seedless' grapes as a function of the concentration of methyl jasmonate applied. Points are treatment means, $\mathrm{n}=5$ ten-berry samples. Fruit detachment force $=0.80+-1.075^{-4} \cdot[$ methyl jasmonate $], r^{2}=0.99$. wine grapes could improve the harvest yield and quality if it enables less aggressive mechanical harvesting so that mechanical damage to machine-harvested fruit is reduced and if less "material other than grape" such as rachis and leaves are sent to the winery (Meyer, 1969). Juice from grapes damaged during harvest may oxidize or ferment before being delivered to the winery (Meyer, 1969).

'Cabernet Sauvignon' berries treated with 4500 ppm MeJA were larger, and their juice had less titratable acidity and a higher $\mathrm{pH}$ than nontreated berries, but treatment did not significantly affect those variables in 'Merlot' (Table 5). The wine grapes were treated and harvested at lower soluble solids than necessary for winemaking $\left(24^{\circ}\right.$ Brix or greater) so that berry phenology was similar to that of 'Thompson Seedless' and 'Crimson Seedless' when those grapes were treated and harvested. Whether the relative maturity of the grapes might affect the efficacy of MeJA sprays is yet to be determined.

In conclusion, application of MeJA was shown to promote loosening of mature grape berries. Loosened berries that abscised or detached from clusters were generally in better physical condition than nontreated
Table 4. Fresh weight and soluble solids of Crimson Seedless berries from clusters treated $14 \mathrm{~d}$ earlier with $0,1125,2250$, or $4500 \mathrm{ppm}$ methyl jasmonate (MeJA).

\begin{tabular}{ccc}
\hline $\begin{array}{c}\text { Treatment, } \\
\text { ppm MeJA }\end{array}$ & $\begin{array}{c}\text { Berry } \\
\text { wt }(\mathrm{g})\end{array}$ & $\begin{array}{c}\text { Soluble solids } \\
\text { (Brix) }\end{array}$ \\
\hline 0 & $5.85^{\mathrm{z}}$ & $20.22 \mathrm{a}$ \\
1125 & 5.41 & $19.76 \mathrm{ab}$ \\
2250 & 5.96 & $19.30 \mathrm{~b}$ \\
4500 & 5.54 & $19.28 \mathrm{~b}$ \\
\hline
\end{tabular}

${ }^{\mathrm{z}}$ Values are treatment means, $\mathrm{n}=5$ 10-berry samples. Means followed by a different letter are significantly different according to Duncan's new multiple range test.

have reduced soluble solids is uncertain, but the formation of an abscission layer could disrupt the vascular system between the pedicel and the berry, thus inhibiting the transfer of soluble solids from the vine to the berry. Treatment with MeJA did not appear to have any other effects on 'Crimson Seedless' berries.

'Cabernet Sauvignon' and 'Merlot' experiments. Treatment with 4500 ppm MeJA reduced FDF of 'Cabernet Sauvignon' and 'Merlot' by $66 \%$ and $75 \%$, respectively, compared with nontreated vines (Fig. 4). The degree to which MeJA reduced FDF of these grape cultivars is comparable to reductions in FDF noted for 'Thompson Seedless' grapes and 'Valencia' oranges (Hartmond et al., 2000). Treatment with MeJA appeared to induce less than $10 \%$ fruit drop in 'Cabernet Sauvignon' and 'Merlot', but fruit drop was not measured. Abscised berries, and most berries detached from treated vines, had formed an abscission layer as described for 'Thompson Seedless' and 'Crimson Seedless'. The fruit-loosening effect of MeJA on

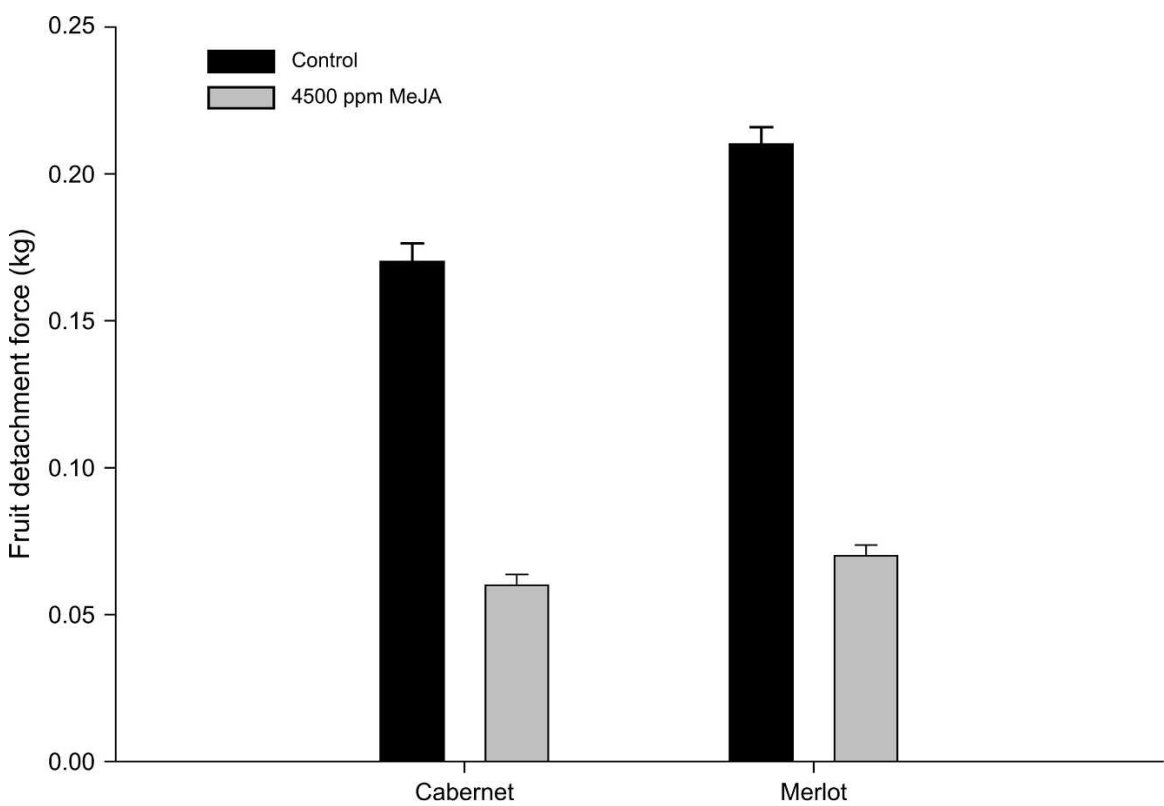

Fig. 4. Fruit detachment force (FDF) of berries from 'Cabernet Sauvignon' (Cabernet) and 'Merlot' grapevines treated with 0 or 4500 ppm methyl jasmonate (MeJA) $14 \mathrm{~d}$ after treatment. Bars represent treatment means and standard errors; within each cultivar, differences in FDF were significant according to analysis of variance $(P<0.05)$.

Table 5. The fresh weight, Brix, titratable acidity (TA), and $\mathrm{pH}$ of berries from Cabernet Sauvignon and Merlot grapevines treated with solutions of 0 or $4500 \mathrm{ppm}$ methyl jasmonate (MeJA) $14 \mathrm{~d}$ after treatment.

\begin{tabular}{|c|c|c|c|c|c|c|c|c|}
\hline \multirow[b]{2}{*}{$\begin{array}{l}\text { Treatment, } \\
\text { ppm MeJA }\end{array}$} & \multicolumn{4}{|c|}{ Cabernet Sauvignon } & \multicolumn{4}{|c|}{ Merlot } \\
\hline & $\begin{array}{l}\text { Berry } \\
\text { wt (g) }\end{array}$ & Brix & TA $(g / L)$ & $\mathrm{pH}$ & $\begin{array}{l}\text { Berry } \\
\text { wt (g) }\end{array}$ & Brix & TA $(g / L)$ & $\mathrm{pH}$ \\
\hline 0 & $1.40^{\mathrm{z}}$ & 19.7 & 0.63 & 3.77 & 1.76 & 23.11 & 0.45 & 3.97 \\
\hline 4500 & 1.57 & 19.4 & 0.52 & 3.86 & 1.77 & 22.82 & 0.46 & 3.98 \\
\hline$P>\mathrm{F}$ & 0.002 & 0.22 & 0.001 & 0.001 & 0.85 & 0.25 & 0.28 & 0.39 \\
\hline
\end{tabular}

${ }^{\mathrm{z}}$ Values are means of four samples each consisting of four whole clusters. 
grapes. Thus, MeJA treatments may improve the quality of machine-harvested grapes. The treatments had little effect on leaves, especially at the lower concentrations that would be most likely to have commercial application. Currently, additional coronatine is being made and will be available in the future for grape abscission research. Additional research is needed to: 1) compare the efficacy of MeJA and coronatine in larger-scale mechanically harvested trials; 2) verify abscission agent concentrations necessary for consistent fruit loosening at multiple grapegrowing sites; 3 ) define target FDF necessary to maximize mechanical removal; 4) establish mechanical harvesting parameters necessary to achieve high fruit removal with low fruit damage; and 5) determine impact, if any, of abscission agent application on long-term vine health and final product quality.

\section{Literature Cited}

Burns, J.K. 2002. Using molecular biology tools to identify abscission materials for citrus. HortScience 37:459-464.

Burns, J.K., L.V. Pozo, C.R. Arias, B. Hockema, V. Rangaswamy, and C.L. Bender. 2003. Coronatine and abscission in citrus. J. Amer. Soc. Hort. Sci. 128:309-315.
Christensen, L.P. 2000a. Current developments in harvest mechanization and DOV. In: L.P. Christensen (ed.). Raisin production manual. UC Agricultural and Natural Resources Communications Services, Oakland, CA.

Christensen, L.P. 2000b. Growth regulators, p. 139-141. In: L.P. Christensen (ed.). Raisin production manual. UC Agricultural and Natural Resources Communications Services, Oakland, CA.

Dennis, F.G., Jr. and J. Hull, Jr. 2003. Deciduous tree fruit. HortScience 38:901-910.

Gomez, K.A. and A.A. Gomez. 1984. Statistical procedures for agricultural research. Wiley Interscience, New York, NY.

Eichorn, K.W. and D.H. Lorenz. 1977. Phäenologische Entwicklungsstadien der Rebe. Nachrichtenbl. Deut. Pflanzenschutzd. (Braunschweig) 29:119-120.

Hartmond, U., R. Yuan, J.K. Burns, A. Grant, and W.J. Kender. 2000. Citrus fruit abscission induced by methyl-jasmonate. J. Amer. Soc. Hort. Sci. 125:547-552.

Meyer, J. 1969. Effect of fruit cane severance of grapevines on must and wine yield and composition. Amer. J. Enol. Viticult. 20:108-117.

Pozo, L., A. Redondo, U. Hartmond, W.J. Kender, and J.K. Burns. 2004. 'Dikegulac' promotes abscission in citrus. HortScience 39:16551658.

Repka, V., I. Fischerova, and K. Silharova. 2001. Methyl jasmonate induces a hypersensitive- like response of grapevine in the absence of avirulent pathogens. Vitis 40:5-10.

Scholefield, P.B., P. May, and T.F. Neales. 1977. Harvest-pruning and trellising of 'Sultana' vines. I. Effects on yield and vegetative growth. Sci. Hort. 7:115-122.

Studer, H.E. and H.P. Olmo. 1971. The severed cane technique and its application to mechanical harvesting of raisin grapes. Trans. ASAE 14:38-43.

Studer, H.E. and H.P. Olmo. 1974. Parameters affecting the quality of machine harvested raisins. Trans. ASAE 17:783-786.

Vasquez, S.J., M.W. Fidelibus, L.P. Christensen, W.L. Peacock, K.M. Klonsky, and R.L. De Moura. 2007. Sample costs to produce raisinsContinuous tray-harvest equipment purchased used and refurbished, San Joaquin Valley. University of California Cooperative Extension. Department of Agricultural and Resource Economics, Davis, CA.

Wang, K.L.-C., J. Li, and J.R. Ecker. 2002. Ethylene biosynthesis and signaling networks. Plant Cell 14:S131-S151.

Weaver, R.J. and R.M. Pool. 1968. Induction of berry abscission in Vitis vinifera by morphactins. Amer. J. Enol. Viticult. 19:121-124.

Yuan, R. and J.K. Burns. 2004. Temperature factor affecting the abscission response of mature fruit and leaves to CMN-Pyrazole and ethephon in 'Hamlin' oranges. J. Amer. Soc. Hort. Sci. 129:287-293 